\title{
THE RISK ASSOCIATED WITH THE REPLACEMENT OF TRADITIONAL BUDGET WITH PERFORMANCE BUDGETING IN THE PUBLIC FINANCE SECTOR MANAGEMENT
}

\author{
Izabela Emerling ${ }^{1, a}$ and Magdalena Wojcik-Jurkiewicz ${ }^{2, b, *}$ \\ ${ }^{1}$ University of Economics in Katowice, Ul. 1 Maia 50, 40-287 Katowice, Poland \\ ${ }^{2}$ University of Economics in Katowice, Ul. 1 Maia 50, 40-287 Katowice, Poland \\ aizabela.emerling@ue.katowice.pl, bm.wojcik-jurkiewicz@ue.katowice.pl \\ ${ }^{*}$ Corresponding author
}

Cite as: Emerling, I., Wojcik-Jurkiewicz, M. (2018). The risk associated with the replacement of traditional budget with performance budgeting in the public finance sector management, Ekonomickomanazerske spektrum, 12(1), 55-63.

Available at: dx.doi.org/10.26552/ems.2018.1.55-63

\begin{abstract}
Performance budgeting has been functioning in Poland for almost twelve years now and it still can be said that it is a challenge for the entire sector. So far many countries have attempted to implement it, proposing a transition from the traditional budget to the performance budgeting. It should be noted that this also causes a change in thinking which does not come too easily, especially in case of managing public administration. In addition, the performance budgeting is a key element of the management system. The purpose of this paper is to show that the replacement of traditional budget with performance budgeting is desirable in public administration. It would lead to the improvement of the quality of state management and as a tool it would allow to effectively monitor and evaluate the results and efficiency of budgetary funds administrators. The performance budgeting is a tool for public governance management. The applied research methods are the method of critical analysis of literature studies and the analysis of the advantages of drawing up a task-based budget in relation to the traditional budget in managing the public finances unit. These methods will be presented in the context of their suitability to demonstrate that it is necessary to convert the traditional budget into a budget in a task setting, in public administration. The basic hypothesis is the assumption that the use of a task-based budget will lead to improvement in the quality of state management, and as a tool it will allow effective monitoring and evaluation of the results and effectiveness of budget part managers.
\end{abstract}

Keywords: performance budgeting, traditional budget, public expenditure, risk, management in the public finance sector

JEL Classification: H61, M10, M41, M19

\section{Introduction}

The issue related to the management of public finances using performance budgeting entails the need to reevaluate the approach to the management of public finances. The aim of performance budgeting is to ensure, through its design, a greater transparency in allocating public funds, thus constituting an effective instrument of public finance management, which is closely linked to the risk. The goal of such approach is to select appropriate methods for the 
The Risk Associated with The Replacement of Traditional Budget with Performance Budgeting in The Public Finance Sector Management Authors: Izabela Emerling, Magdalena Wojcik-Jurkiewicz

efficient use of resources to achieve its goals and objectives. Performance budgeting can contribute to a more effective prioritization of public spending and also to reduction of the asymmetry of information between centres generating spending and their control centres. At the same time the importance of management and monitoring of the elements of performance budgetinging are emphasised, which need to be strengthened in order to provide the added value of social participation.

The purpose of this paper is to demonstrate that the introduction of performance budgeting, regardless of the method, brings only the benefits for decision makers who have more complete information on how are the public funds spent.

The applied research methods are the method of critical analysis of literature studies and the analysis of the advantages of drawing up a task-based budget in relation to the traditional budget in managing the public finances unit. These methods will be presented in the context of their suitability to demonstrate that it is necessary to convert the traditional budget into a budget in a task setting, in public administration. The basic hypothesis is the assumption that the use of a task-based budget will lead to improvement in the quality of state management, and as a tool it will allow effective monitoring and evaluation of the results and effectiveness of budget part managers, in accordance with Swietla \& Wojcik-Jurkiewicz (2017), and Schmidt (1992).

\section{Methodology and Literature Review}

Activity-based performance budgeting has been interpreted many times but it is still not uniformly understood. The literature also provides many different definitions of this type of budgeting. The essence of performance budgetinging lies in a "precise definition of the activities to be financed from the state budget and the application of appropriate measures that would allow evaluation of the results obtained as a result of the budget expenditures." According to Lubinska (2007) "the essence of performance budgetinging is the introduction of public expenditure management by objectives adequately substantiated and hierarchized in order to achieve certain effects, as measured by the established system of measures.", in accordance also with Wildavsky (1978). Another interpretation of this term is proposed by Owsiak (2005). According to him it is a "public entity financial plan, in which, regardless of the current classification of budget revenue and expenditure, are given specific activities characterized by homogeneity. The activity has a (quantitatively and qualitatively) specified purpose, cost and efficiency ratio. There is also a person indicated as the person responsible for its implementation."

The provisions of the Public Finance Act introduced the definition of the so-called performance budgetinging system, which consists of a statement of state expenditures or the cost of public sector entities prepared in accordance with the function of the state, describing individual areas of state activities, and budgetary tasks grouping expenditures by purpose, budgetary subtasks grouping actions enabling the implementation of the objectives of the task, in which subtasks have been separated along with a description of the purpose of these tasks and subtasks, as well as the base and target achievement indicators of the objectives of state activity .

Regardless of the scope of definition, the ABB presents a new tool to perform activities with simultaneous monitoring of public spending on these activities. The most important activities include following Table 1 . 
Table 1: The most important activities for $A B B$

The most important activities for ABB
Improving management and budgetary processes
Creating the hierarchy of the planned projects
Determining the likely costs of the activities taken into account in the budget
Defining objectives to be achieved through the implementation of the activities
Selecting a group of measures to evaluate the achieved effects
Assigning responsibilities to specific individuals (departments, offices),
for implementation of individual activities
Improving the level of work performed by employees
Budget planning co-created by the workforce
Determining the workload of scheduled activities
Understandable form of the budgeting

Source: author's compilation according to Winiarska (2012)

Improvement of the management and budgeting processes should be understood as the desire to achieve professional budget planning in the context of the next few years and not in the context of one year as is presently the case, in accordance with Popesko \& Socova (2016). This requires an extensive knowledge and experience from the persons responsible for the management of a given entity, argued by Wang (2002).

The hierarchy of the planned projects is based on defining the order of implemented activities according to their relevance to the needs of a given community. Determination of the likely costs of the activities by splitting the main objectives (few years) into activities (short periods), which are included in the budget, estimating their costs, in accordance with Bleyen, Lombaert \& Bouckaert (2015). This allows determining the total cost of the entire project, as opposed to the traditional budgeting, in which the cash method prevails.

Defining the objectives to be achieved through the implementation of the activities that are the basis of transparent and comprehensive plan of activities of the entity (with detailed activities compatible with the expectations of the people from a given community).

Selection of a group of measures to evaluate the achieved effects is a major challenge for local governments. It is important to note that the cost measures should be combined with measures of the actual implementation of a given activity in order to get a real measurement of the activity results.

Assigning responsibilities for each activity to specific individuals. Performed activities are clearly defined and allocated to the departments according to their scope. Determining the workload of scheduled activities in the future may contribute to the effective use of human resources and create a basis for a rational employment.

The modern world has changed since 1989 when Poland made a number of changes in the economic sphere. The crisis in the global market in recent years has affected significantly the sphere of finance and thereby showed that there are needed some changes in this area in order to avoid similar problems or reduce them in the future, stated by Kozuch (2004). It is therefore important to introduce modern management of the public finances in a wider environment, i.e. at the state level, as well as in a narrower environment, i.e. in local government entities, which will increase the efficiency and effectiveness of activities, according to Filipiak (2011). To meet these requirements, a new concept of public finance management was introduced in the nineties of the twentieth century, which is aimed at effective management and disbursement of available resources. The new approach is an alternative to the traditional (bureaucratic) model, which aims to apply the solutions used so far in the private sector, which are focused on achieving the desired results and evaluation of the activities with the use of well-defined measures. It is very important for the effective, stated by Winiarska (2012), and management in public sector entities, stated by Swiderek (2012). 
The Risk Associated with The Replacement of Traditional Budget with Performance Budgeting in The Public Finance Sector Management Authors: Izabela Emerling, Magdalena Wojcik-Jurkiewicz

Poland, since the entry into the European Union, has to employ the guidelines on modern public finance management. A tool that meets all the standards in this regard is the performance budgeting system. The first records of performance budgetinging emerged in the Public Finance Act of June 30th, 2005. Restructuring of public finances in the government sector was started in 2006. Specific guidelines for a new form of budgeting were introduced in a short form for 2008 and in 2009 they were expanded to compensate for the earlier shortcomings. The new activity-based system has introduced, in addition to the division of tasks and subtasks, functions of the state. Each activity was assigned with objectives and specifically chosen measures for each one of them (www.mf.gov.pl).

The schedule of works on performance budgeting had been developed for the years of 2008-2015, which assumed that the performance budgeting would be first presented in the budget act in parallel with the traditional budget in 2013. These assumptions have been achieved but it is much harder to make the implementation of the new system at the local government level. Problems also arise at the level of provincial offices. The beginnings of introduction of the performance budgeting system into government units date back to 1994 . The precursor to changes in budgeting was the city of Krakow.

\section{Results}

A financial budget is the annual financial plan of income and expenditure as well as revenues and disbursements of a given entity (state or local government), in accordance with Robinson \& Last (2009). If it concerns the state budget or the budget resolution, it is enacted in the form of a budget act. The budget forecast is based on historical data mostly from the previous year and adjusted so as to achieve the intended results, stated by Nnoli, Adeyemi \& Onuora (2016). During the calendar (budget) year the budget can be changed. These changes can be made by decision making body (municipal council) and an executive body (commune head, mayor, president) depending on the administrator.

The traditional budget plays an important part in management of public finance sector entities, argued by Chan (2003). Often referred to in the literature as the classic budget, is developed on the basis of budget classification, which creates a precise and uniform system of grouping the revenues and expenditures for the whole public sector. It is a key element of the budget system. The basis for separation of particular classifications is the prioritisation of expenditures and revenues according to an appropriate criterion. After that the unified classification system creates the conditions for comparability, argued by Zawadzka-Pąk (2013). In Poland, the classification system is determined by the Minister of Finance, who introduces an appropriate regulation in this regard. The budget can be a management tool only if it makes it easier to link spending with effects set for the few following years, according to Diamond (2003). Examination of the results in the traditional budget is sometimes extremely difficult and sometimes even impossible through a person or body to which the budget resources are allocated. An additional concretising measure of reallocating expenditure is to show their economic nature, argued by Owsiak (2002). The existing division of budget classification for parts, sections, chapters and paragraphs creates a lot of problems when assessing the budget in classic terms because the structure of spending is non-homogenous. By this it should be understood that expenditure at the level of sections is an objective division, which involves the separation according to institutions. However, parts and chapters are of objectively-subjective character, which causes problems in distinguishing of carried out activity from the entity that carries it out. 
In addition, the task is characterized by long-term effect, regularity and continuity. This creates a difficulty in applying the traditional budget, which is characterized by annuality when activities cover periods of several years, argued by Suppa \& Webb (2016). Managers of entities must determine a plan of action and the hierarchy of the investment. Poorly defined strategy can contribute to a reduction in the pace of economic and social development and impoverishment of the local community. The standard budget (Winiarska, 2012, p.20) should be considered as an instrument with which public funds are used. Performance budgeting, however, focuses on efficiency which makes it a tool of modern management. Performance budgeting is an alternative to the standard method of preparation and implementation of the budget, stated by Krol (2016). The main objective of performance budgeting is an effective management of the activity of a given entity by setting clear, easy to understand objectives established at the planning stage that will be achieved with the help of activities, stated by Dokalskaya (2014). Scope of information is much wider because of the efficiency part (activity-based) compared to traditional, argued by Fryer \& Ogden (2009). It informs about the purpose of the spending and the results obtained from expenditures. To properly interpret the results, the measure should be accordingly adapted and specified, according to Pietrzak (2011). This essential difference makes the budget of this type create a full picture of the situation and causes it to be qualitatively better source of data. Other perspectives are created by functional (activity) classification in the performance budgeting. It makes a distinction only with the use of subject criterion, i.e. estimating expenditure by type and quantity as well as quality of public services, stated by Czarnecka (2016). A common feature of the two budgets is a refinement of criterion for the allocation of expenditure by economic classification.

It is worth recalling that the traditional budget is evaluated in terms of exceedances of established limits, while sctivity-based budget is set to achieve the planned objectives. The degree of realization of these activities can be estimated using appropriate measures, stated by Webb \& Candreva (2010). The first column of Table 2 below presents features of traditional budget, while the second shows the performance budgeting.

Table 2: The differences between the traditional and performance budgeting

\begin{tabular}{|c|c|}
\hline Traditional Budget & Performance Budgeting \\
\hline Expenditure tool & Management tool \\
\hline $\begin{array}{l}\text { Difficulties in integration of the } \\
\text { objectives } \\
\text { of the self-government with control of } \\
\text { performance } \\
\text { of given activities }\end{array}$ & $\begin{array}{l}\text { Improves the definition of functioning } \\
\text { objectives } \\
\text { of self-government and examination of } \\
\text { the effectiveness of their implementation }\end{array}$ \\
\hline Limited prioritization of expenditures & $\begin{array}{l}\text { Hierarchy of tools and expenditures } \\
\text { (depending on the needs of residents) }\end{array}$ \\
\hline $\begin{array}{l}\text { Construction of the budget is subject to } \\
\text { the limits imposed on expenditure groups }\end{array}$ & $\begin{array}{l}\text { Defining activities and assign them with } \\
\text { specific costs, } \\
\text { which are the foundation for determining } \\
\text { ABB }\end{array}$ \\
\hline The rigid approach (applies to one year) & Long-term planning (covers a few years) \\
\hline $\begin{array}{l}\text { Lack of information about the } \\
\text { effectiveness of expenditures }\end{array}$ & $\begin{array}{l}\text { Researching expenditures in respect to } \\
\text { their effects }\end{array}$ \\
\hline $\begin{array}{l}\text { Knowledge of expertise on budgetary } \\
\text { classification }\end{array}$ & $\begin{array}{l}\text { Clear information on the expenditure } \\
\text { budget for particular activities }\end{array}$ \\
\hline
\end{tabular}


The Risk Associated with The Replacement of Traditional Budget with Performance Budgeting in The Public Finance Sector Management Authors: Izabela Emerling, Magdalena Wojcik-Jurkiewicz

Directs conversations in councils and
municipalities on selected items of
expenditure

Head of the entity allocates the funds

Budgetary rules are not rigid rules, but their content is being transformed due to changes in state functions and socioeconomic conditions of the country
Facilitates a substantive debate in local government entities

Head of the entity manages funds

Budgetary rules may be subject to revision in case it leads to improvement in management of public funds

Source: Own elaboration based on: Hansen (2011), Niculescu \& Leustean (2014), Ruggeri, et al. (2017), Alam \& Nandan (2008), Roehm \& Castellano (1977), Whitmore (1980), Dooren, Bouckaert \& Halligan (2010), Dunleavy \& Hood (1994), Covaleski, Dirsmith \& Jablonsky (1985), Lubinska (2007), Winiarska (2012), Chowdhury \& Shil (2016), Swietla \& Wojcik-Jurkiewicz (2017), Bleyen, Lombaert \& Bouckaert (2015)

\section{Discussion}

In the public finance sector entities, the most important objective when designing and implementing the budget should be the implementation rent of the set objectives. It is worth noting that traditional budget is a spending plan based on budget classification: part - section chapter, while the performance budgeting expands the spending plan with further information related mainly to the new improved classification of activities, which is contained in contingency note. In addition, two classifications currently being used cause a whole range of implications in the functioning of public finances. It is even possible to point the risk of "bad spending" of public funds through:

- the need to keep records in two different ways, resulting in additional burdens for public administration,

- difficulties in assessing the status and directions of development of the public finance sector, as this involves analyzing two different systems of classification and understanding of the differences between them,

- difficulties in deciding on the shape of the budget act by MPs, who must be able to accurately relate the consequences of their decisions to the traditional and activitybased systems,

- inconsistency in the institutional and legal system due to the fact that some data such as the National Long-term Financial Plan, is presented only in activity-based system but result in provisions, which have consequences for subsequent budget acts, which are prepared both in the traditional and activity-based systems.

Some of the selected examples of the implications arising from the use of two different methods of classification, which may become the main cause of the risk arising from a revolution in the institutional arrangement of the public sector, associated with implantation of the traditional classification among administration personnel, and thus the efficiency in the use of this method, according to Robinson (2013), Lorain et al. (2015), Harasym et al. (2017), Alam \& Lawrence (1994).

Two basic differences in the traditional and activity-based system of budgeting. The first one refers to the traditional budget, which informs the recipient what generic costs and in what amount have to be paid to maintain them and give them the ability to perform the activities outlined by regulations and statutes. The second is used in performance budgetinging, which answers the question: What is the cost of activities carried out by kindergartens? What are the results (effects) of these expenditures, argued by Robinson (2007)? The degree of realization of a sample objective should be determined by specific measures. 
Zawadzka-Pak (2013) states that performance budgeting is not the subject of the regulations of applicable financial law and replacement of the existing budget (traditional) with new in the form of $\mathrm{ABB}$ is the subject of works on future changes in financial law conducted by the Ministry of Finance, also find in Smith (2007), and Roberts et al. (2000). The adoption of performance budgeting based on the principle of "voluntariness," which in turn does not contribute to the widespread development and use by all budget entities means that this process will be slow. Effective operation of performance budgeting is possible only in case of the properly prepared reform, according to Van Dooren, Bouckaert, \& Halligan (2010). Smith (2007) rightly states that "it does not seem advisable or possible to make a quick and simultaneous and obligatory implementation of performance budgetinging in all local government entities." This involves a great diversity of entities. In recent years there has been a significant increase in the use of innovative solutions in the management of public finances. Therefore, a better solution is "voluntary" and "gradual" introduction of performance budgeting with the possibility of division into several stages, at the same time using extensive advertising campaign and training in this area.

Another condition for the application of elements of performance budgetinging is currently manifested in limitation concerning the amendment of the planned and determined amount of expenditures approved for implementation of perennial projects.

It is worth noting that under the current state law, the performance budgeting document often functions in parallel with the budget resolution, budget execution and annual financial plans in force under the provisions of the Public Finance Act. Compared with the above mentioned plans, the performance budgeting does not include all items of the budget under the Public Finance Act, but it is mainly expenditure estimation of budgetary activities.

When $\mathrm{ABB}$ is prepared properly1, it will allow the execution of scheduled activities despite the fact that it officially does not apply and the budget in traditional terms will only be a parallel form of presentation of income and expenditure of the state.

This causes a lot of difficulties when deciding on the introduction of performance budgeting, which is voluntary and not mandatory because in addition to the newly introduced performance budgeting, the budget in the traditional sense must be carried out simultaneously, argued by Heinrich (2004). Entities which have accepted the challenge and introduced ABB must first develop a traditional budget because it is a valid form, and then once a year or once a quarter develop additional information and attach it as an performance budgeting. Such actions cause aversion in the approach of the ruling authorities to change their attitude of public finance management and effective management of public resources.

\section{Conclusion}

Presented in this paper concept of replacement of traditional budget in the entities of public finance sector with a performance budgeting points to the possibility of making such a conversion, but at the cost of introduction of many changes in areas associated with previous „habits" associated with traditional budget. It points to the fact that the execution of such a change in practice will be paid for with opposition from the staff employed in the public sector, employing so far mainly traditional classifications.

In conclusion, the concept of risk management in the public finance system should mean that:

\footnotetext{
${ }^{1}$ Note: The order of ABB preparation is important, that is: define the activities, specific terms, the value of the amounts needed for implementation, then define the objectives and measures of evaluation and prepare a statement of expenditure in the form of performance budgeting.
} 
The Risk Associated with The Replacement of Traditional Budget with Performance Budgeting in The Public Finance Sector Management Authors: Izabela Emerling, Magdalena Wojcik-Jurkiewicz

- $\quad$ in the performance budgeting it should be specified who exactly manages the risk and is responsible for this risk,

- $\quad$ risk management is carried out at all levels of the public sector entities,

- $\quad$ there is used a complementary methodical workshop in the field of risk management closely related to the prioritization of expenditure,

- $\quad$ risk management of the performance budgeting should be done in the public sector on a continuous basis and currently the frequency of dealing with performance budgeting takes place mostly on a quarterly basis, and at the least it is undertaken once a year in the processual dimension,

- $\quad$ an effective risk management in the public finance sector reduces the risk of its operation.

Consistent implementation of budgetary activities and spending of public funds for these purposes in accordance with the traditional classification is at risk of constantly growing state budget deficit, which may cause bankruptcy.

\section{References}

Alam, M., \& Lawrence, S. (1994). A New Era in Costing and Budgeting: Implications of Health Sector Reform in New Zeland. International Journal of Public Sector Management, 7(6), 41-51.

Alam, M., \& Nandan, R. (2008). Management Control Systems and Public Sector Reform: A Fijian Case Study. Accounting, Accountability and Performance, 14(1),1-28.

Bleyen, P., Lombaert, S. \& Bouckaert, G. (2015). Measurement, Incorporation and Use of Performance Information in the Budget a Methodological Survey Approach to Map Performance Budgeting Practices in Local Government. Society and Economy (37)3, 331-355.

Covaleski, M.A., Dirsmith, M.W. \& Jablonsky, S.F. (1985). Traditional and Emergent Theories of Budgeting An Empirical-Analysis. Journal of Accounting and Public Policy, 4(4), 277-300.

Czarnecka, A. (2016). Performance Budgeting As a Tool For Financial Management of Local Government. Trends of Management in the Contemporary Society, 269-272.

Dokalskaya, I. (2014). Performance-based Budgeting in the Public Sector: Between Discourse and Effective Management. dspace-uniud.cineca.it

Dooren, W.V., Bouckaert, W.G., \& Halligan, J. (2010). Performance Management in the Public Sector. London, Great Britain: Routledge.

Dunleavy, P. \& Hood, C. (1994). From Old Public Administration to New Public Management. Public Money \& Management, 14(3), 9-16.

Filipiak B. (2011). Finanse Samorzadowe Nowe Wyzwania Bieżace I Perspektywiczne. Warszawa, Poland: Difin S.A.

Fryer, K.J.A. \& Ogden, S. (2009). Performance Management in the Public Sector. International Journal of Public Sector Management, 22(6), 478-98.

Niculescu, N. \& Leustean, B. (2014). Activity Based Costing (ABC) and Performance Measurement through the Budgeting (ABB). Proceedings of the 24th International-Business-Information-Management-Association. Milan, Italy: 713-719.

Nnoli, U. F., Adeyemi, S.S. \& Onuora, O.A. (2016). Zero-Based Budgeting: Pathway to Sustainable Budget Implementation in Nigeria. Business Trends, 6(3), 28-35.

Hansen, S.C. (2011). A Theoretical Analysis of the Impact of Adopting Rolling Budgets, ActivityBased Budgeting and Beyond Budgeting. European Accounting Review, 20(2), 289-319.

Harasym, R., Rodzinka, J. \& Skica, T. (2017). The Size of Local Government Administration at a Municipal Level as a Determinant of Entrepreneurship. Journal of Entrepreneurship, Management and Innovation (JEMI), 13(2), 5-32.

Heinrich, C. J. (2004). Improving Public Sector Performance Management: One Step Forward, Two Steps Back? Public Finance and Management, 4(3), pp. 317-351.

Chan, J.L. (2003). "Government Accounting: An Assessment of Theory, Purposes and Standards". Public Money and Management, 23(1), pp. 13-20.

Chowdhury, A. \& Shil, N. C. (2016). Innovation in Public Sector Management Control Systems in the Context of New Public Management: A Case of an Australian Public Sector Organization. Journal of Entrepreneurship, Management and Innovation, 12(4), 99-125. 
Kozuch B. (2004). Zarzadzanie Publiczne W Teorii I Praktyce Polskich Organizacji. Warszawa, Poland: Wydawnictwo Placet.

Krol D. (2016). Estimation of Management Instruments of Local Government Finances in the Light of Paradigm Evolution of Public Funds. Nauki o Finansach Financial Sciences, 1(26).

Lorain, M-A. Garcia D.A. \& Sastre Pelaez, F. (2015). Traditional budgeting during financial crisis. Cuadernos De Gestion, 15(2), 65-89.

Lubinska, T. (2007). Budżet Zadaniowy w Polsce. Warszawa, Poland: Wydawnictwo Difin.

Owsiak, S. (2002). Budżet Władz Lokalnych. Warszawa, Poland: Polskie Wydawnictwo Ekonomiczne.

Owsiak S. (2005). Finanse Publiczne. Teoria i Praktyka. Warszawa, Poland: Wydawnictwo Naukowe PWN.

Pietrzak, U. (2011). Budżet Zadaniowy i Wydatki Strukturalne w Instytucjach Kultury. Gdańsk, Poland: Ośrodek Doradztwa i Doskonalenia Kadr Sp. z o.o.

Popesko, B. \& Socova, V. (2016). Current Trends in Budgeting and Planning: Czech Survey Initial Results. International Advances in Economic Research; Edwardsville (22) 1, 99-100.

Roberts, M, Muras, A \& Paschall, D. (2000). Planning and Budgeting for Quality: An ActivityBased Approach. Proceedings of the 54th Annual Quality Congress. Indianapolis: 618-626.

Robinson, M. \& Last, D. (2009). A Basic Model of Performance-Based Budgeting. International Monetary Fund. Fiscal Affairs Department

Robinson, M. (2007). Performance Budgeting Models and Mechanisms. In M. Robinson (Ed.) Performance Budgeting. Linking Funding and Results. New York, Palgrave Macmillan.

Robinson, M. (2013). Performance based Budgeting. Clear PB Manual, Springer.

Roehm, H.A. \& Castellano, J.E. (1977). Zero-Base Budgeting - Comparison With Traditional Budgeting. Cost and Management, 51(6), 4-\&.

Ruggeri, M. et al. (2017). Activity-Based Costing and Budget Analysis of Vedolizumab Versus Conventional Treatments in Ulcerative Colitis and Crohn's Disease. Global \& Regional Health Technology Assessment, 4(1), E88-E99.

Schmidt, J.A. (1992). Is It Time to Replace Traditional Budgeting. Journal of Accountancy, 174(4), 103-107.

Smith, P. (2007). Performance Budgeting in England: Public Service Agreements. In M. Robinson (Ed.) Performance Budgeting. Linking Funding and Results. New York, USA: Palgrave Macmillan.

Suppa, A. \& Webb, N. J. (2016). What Factors Contribute to Success in Performance Management in The Public Sector? An International Comparative Study of Two Large Defense Organizations. International Public Management Review, 17(2), 1-35.

Swiderek, I. (2012). Budżet Zadaniowy i Strategiczna Karta Wyników w Jednostkach Samorządu Terytorialnego. Gdańsk, Poland: Ośrodek Doradztwa i Doskonalenia Kadr Sp. z o.o..

Swietla, K. \& Wojcik-Jurkiewicz, M. (2017). Centrum Usług Wspólnych Współczesną Koncepcją Adaptacji Rozwiązań Biznesowych na Poziomie Samorządów, Rozdział. Warszawa, Poland: K. Świetla, Difin.

Ustawa z 27 sierpnia 2009 roku o finansach publicznych, Dz.U. $2009 \mathrm{Nr}$ 157, poz. 1240 ze zm.

Van Dooren, W., Bouckaert, G., \& Halligan, J. (2010). Performance Management in the Public Sector. London, Great Britain: Routledge

Wang, X. (2002). Assessing Performance Measurement Impact: A Study of US Local Governments. Public Performance \& Management Review, 26(1), 26-43.

Webb, N.J. \& Candreva, P.J. (2010). Diagnosing Performance Management and Performance Budgeting Systems: A Case Study of the US Navy. Public Finance and Management, 10(3), 524-555.

Wildavsky, A. (1978). Budget for All Seasons - Why Traditional Budget Lasts. Public Administration Review, 38(6), 501-509.

Winiarska, K. (2012). Budżet Zadaniowy w Teorii i Praktyce. Warszawa, Poland: Wydawnictwo C.H. Beck.

www.mf.gov.pl

Whitmore, H.W. (1980). Un-Balanced Government Budgets, Private Asset Holdings, And The Traditional comparative Static Multipliers. Journal Of Macroeconomics, 2(2), 129-157.

Zawadzka-Pąk, U. K. (2013). Budżet Zadaniowy w Jednostkach Sektora Finansów Publicznych. Gdańsk, Poland: Ośrodek Doradztwa i Doskonalenia Kadr Sp. z o.o. 